\title{
NMR resonance assignments for the active and inactive conformations of the small G protein RalA
}

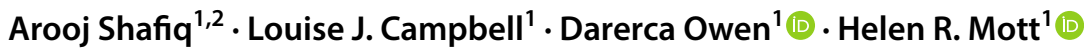

Received: 4 December 2019 / Accepted: 26 December 2019 / Published online: 8 January 2020

(c) The Author(s) 2020

\begin{abstract}
The Ral proteins (RalA and RalB) are small G proteins of the Ras family that have been implicated in exocytosis, endocytosis, transcriptional regulation and mitochondrial fission, as well as having a role in tumourigenesis. RalA and RalB are activated downstream of the master regulator, Ras, which causes the nucleotide exchange of GDP for GTP. Here we report the ${ }^{1} \mathrm{H},{ }^{15} \mathrm{~N}$ and ${ }^{13} \mathrm{C}$ resonance assignments of RalA in its active form bound to the GTP analogue GMPPNP. We also report the backbone assignments of RalA in its inactive, GDP-bound form. The assignments give insight into the switch regions, which change conformation upon nucleotide exchange. These switch regions are invisible in the spectra of the active, GMPPNP bound form but the residues proximal to the switches can be monitored. RalA is also an important drug target due to its over activation in some cancers and these assignments will be extremely useful for NMR-based screening approaches.
\end{abstract}

Keywords Ras $\cdot$ Gtpase $\cdot$ Ral $\cdot$ Signalling $\cdot G$ Protein

\section{Biological context}

The Ral small G proteins are members of the Ras superfamily and are regulated by Ras, which activates guanine nucleotide exchange factors (GEFs) that act on the Ral proteins. The RalGEFs sanction the removal of GDP from the Ral proteins, thereby permitting its replacement by GTP, which is more abundant in the cell (Bodemann and White 2008; Cooper et al. 2013). Once GTP-bound, the Ral proteins are active and can interact with various downstream effectors, including: components of the exocyst complex, Sec5 (Fukai et al. 2003) and Exo84 (Jin et al. 2005); RalBP1 (also known as RLIP76) (Fenwick et al. 2010); the Y-box transcription factor ZONAB (Frankel et al. 2005); and phospholipases C- $\delta 1$ (Sidhu et al. 2005) and D1 (Jiang et al. 1995). The Ral proteins regulate a variety of cellular processes through these effector molecules including exocytosis, endocytosis, actin cytoskeletal dynamics, transcriptional activation and

Helen R. Mott

hrm28@cam.ac.uk

1 Department of Biochemistry, 80, Tennis Court Road, Cambridge CB2 1GA, UK

2 Present Address: Barrett Hodgson University, Korangi Creek, Salim Habib Campus, NC-24, Deh Dih, Korangi Creek, Karachi 74900, Sindh, Pakistan mitochondrial fission. In addition, Ral proteins have been implicated in the initiation and regulation of oncogenic transformation of human cells (van Dam and Robinson 2006). The Ral proteins like other small $G$ proteins act as molecular switches, which cycle between GTP bound active and GDP bound inactive states. They contain two dynamic switch regions [switch I (residues 41-51) and switch II (residues 69-81)], which are involved in effector binding and undergo conformational changes upon nucleotide exchange (Milburn et al. 1990). There are two Ral isoforms, RalA and RalB, which have approximately $85 \%$ sequence identity and in vitro bind with similar affinities to their effectors (Campbell et al. 2015). In vivo however, RalA and RalB appear to perform distinctive functions in normal cells and to play different roles in tumourigenesis and cancer progression. The sequence differences are mainly within the C-terminal, hypervariable region of RalA and RalB, and indeed all of the residues known to contact effector proteins are conserved (Mott and Owen 2010). There is also a single residue insertion in the loop between helix $\alpha 3$ and strand $\beta 5$, which, while not contacting effectors directly, is close to the effector binding regions. These differences are likely to determine differential Ral protein interactions with their effector molecules (Campbell et al. 2015; Shipitsin and Feig 2004). Furthermore, the divergent C-terminal region of Ral 
proteins is also thought to determine their cellular localization (Shipitsin and Feig 2004).

The resonance assignments for RalB-GMPPNP were published in 2007 (Prasannan et al. 2007) but there are no resonance assignments currently available for RalA. Here, we report the backbone and sidechain assignments for RalA bound to the non-hydrolysable GTP analogue, GMPPNP. We also report the backbone amide assignments for the GDP bound, inactive form of RalA.

\section{Methods and experiments}

Uniformly ${ }^{15} \mathrm{~N}$ - and ${ }^{15} \mathrm{~N},{ }^{13} \mathrm{C}$-labelled simian RalA G domain (residues 1-184) containing the activating Q72L mutation was expressed and purified as described earlier (Campbell et al. 2015). The bound nucleotide was exchanged for GMPPNP (Sigma) as described previously (Thompson et al. 1998). Uniformly ${ }^{15} \mathrm{~N}$ and ${ }^{15} \mathrm{~N}-{ }^{13} \mathrm{C}$ wild type (wt) RalA G domain (residues 1-184) was also expressed and purified as described above. To prepare a protein sample bound only to GDP, wt RalA was incubated at $25{ }^{\circ} \mathrm{C}$ for 16-20 h to allow complete hydrolysis of the bound GTP. HPLC analysis was used to confirm the identity of all bound nucleotides.

NMR samples contained $0.26 \mathrm{mM}$ and $0.45 \mathrm{mM}$ of ${ }^{15} \mathrm{~N}$ - and ${ }^{15} \mathrm{~N},{ }^{13} \mathrm{C}$-labelled Q72L RalA-GMPPNP respectively or $0.75 \mathrm{mM}$ of ${ }^{15} \mathrm{~N}$-labelled wt RalA.GDP in NMR buffer (20 mM Tris-HCl, pH 7.6, $150 \mathrm{mM} \mathrm{NaCl}, 1 \mathrm{mM}$ $\mathrm{MgCl}_{2}, 0.05 \% \mathrm{NaN}_{3}$ ) with an additional $10 \% \mathrm{D}_{2} \mathrm{O}$. All NMR spectra were acquired on a Bruker DRX500 spectrometer at $298 \mathrm{~K}$ except ${ }^{13} \mathrm{C}$ HSQC, HCCH-TOCSY and ${ }^{13} \mathrm{C}$-separated NOESY experiments, which were recorded on a Bruker DRX800 at $298 \mathrm{~K}$. The following experiments were recorded on ${ }^{15} \mathrm{~N},{ }^{13} \mathrm{C}$-labelled Q72L RalA.GMPPNP: $\mathrm{HNCA}, \mathrm{HN}(\mathrm{CO}) \mathrm{CA}, \mathrm{HNCACB}, \mathrm{CBCA}(\mathrm{CO}) \mathrm{NH}, \mathrm{HCCH}-$ TOCSY, ${ }^{13} \mathrm{C}$ HSQC, and ${ }^{13} \mathrm{C}$-separated NOESY. ${ }^{15} \mathrm{~N}$ HSQC,${ }^{15} \mathrm{~N}$-separated TOCSY and ${ }^{15} \mathrm{~N}$-separated NOESY experiments were recorded on ${ }^{15} \mathrm{~N}$-labelled samples of both Q72L RalA.GMPPNP and wt RalA.GDP. A 2D homonuclear ${ }^{1} \mathrm{H}$ NOESY was recorded on $0.70 \mathrm{mM}$ unlabelled Q72L RalA.GMPPNP. All NOESY experiments were recorded with $100 \mathrm{~ms}$ mixing times. NMR data were processed using AZARA (Boucher, https://www.bioc.cam.ac.uk/azara), and analysed using CCPN Analysis (Vranken et al. 2005).

For Q72L RalA.GMPPNP the backbone assignments were achieved using standard triple resonance methodology (Gardner and Kay 1998).The sidechain resonances were assigned using the triple resonance experiments (HNCACB, CBCA(CO)NH), in combination with ${ }^{15} \mathrm{~N}$-separated TOCSY and HCCH-TOCSY experiments, as well as ${ }^{15} \mathrm{~N}$-separated and ${ }^{13} \mathrm{C}$-separated NOESY. Sidechain resonances of aromatic residues were assigned using the aromatic region of a ${ }^{13} \mathrm{C} \mathrm{HSQC}$ and the relevant planes in the ${ }^{13} \mathrm{C}$-separated NOESY. Assignments were validated by the presence of return peaks in the related ${ }^{13} \mathrm{C} \beta$ planes. The methyl groups of methionine were identified using their strong peaks at distinct chemical shifts in the ${ }^{13} \mathrm{C}$ HSQC and the sign of the crosspeaks in constant time ${ }^{13} \mathrm{C}$ HSQC. Sidechain amide resonances for Asn, Gln and Arg were assigned using the ${ }^{15} \mathrm{~N}$-separated and ${ }^{13} \mathrm{C}$-separated NOESY spectra. The $2 \mathrm{D}$ homonuclear ${ }^{1} \mathrm{H}$ NOESY was used to identify proton chemical shifts for the bound GMPPNP. The backbone resonances for wt RalA.GDP were assigned with the aid of the assignments of Q72L RalA.GMPPNP, in combination with the ${ }^{15} \mathrm{~N}$-separated NOESY and TOCSY and ${ }^{15} \mathrm{~N}$ HSQC recorded on both proteins (Clore and Gronenborn 1998a, b; Marion et al. 1989).

\section{Assignments and data deposition}

Backbone resonances were never observed for the $11 \mathrm{~N}$-terminal residues (1-11) of RalA. Subsequent electrospray ionisation mass spectrometry (ESI-MS) analysis showed that the N-terminus of RalA undergoes proteolysis in solution. This region is not the part of G-domain of Ral proteins (Bourne et al. 1991) and was similarly absent (and therefore unassigned) in RalB (Fenwick et al. 2009; Prasannan et al. 2007).

The complete backbone assignments were obtained for residues 12-184 of Q72L RalA-GMPPNP except for residues 43-49, which are within switch I, and 68-70, which are in switch II. The statistics for the backbone assignments are shown in Table 1 . The ${ }^{1} \mathrm{H}-{ }^{15} \mathrm{~N}$ HSQC spectrum showing the spectral quality and the assignments is shown in Fig. 1. The switch I (41-51) and switch II (68-81) regions in small $\mathrm{G}$ proteins exhibit internal mobility in the active form, on a timescale that makes their assignment problematic (Feltham et al. 1997; Kraulis et al. 1994; Mott et al. 1999). The missing assignments in these regions were therefore not surprising.

Sidechain assignments were achieved for all residues with observable backbone resonances in $\mathrm{Q} 72 \mathrm{~L}$

Table 1 Extent of assignments of RalA in the active (GMPPNP) and inactive (GDP) forms

\begin{tabular}{lllll}
\hline & Atom & $\begin{array}{l}\text { Number of } \\
\text { expected }\end{array}$ & $\begin{array}{l}\text { Number } \\
\text { assigned }\end{array}$ & $\begin{array}{l}\text { Percentage } \\
\text { assignment } \\
(\%)\end{array}$ \\
\hline RalA.GMPPNP & $\mathrm{HN}$ & 171 & 162 & 94.7 \\
(Q72L) & ${ }^{15} \mathrm{NH}$ & 173 & 162 & 93.6 \\
& ${ }^{13} \mathrm{C}$ & 173 & 165 & 95.4 \\
RalA.GDP & $\mathrm{HN}$ & 171 & 169 & 98.8 \\
& ${ }^{15} \mathrm{NH}$ & 173 & 169 & 97.7 \\
\hline
\end{tabular}




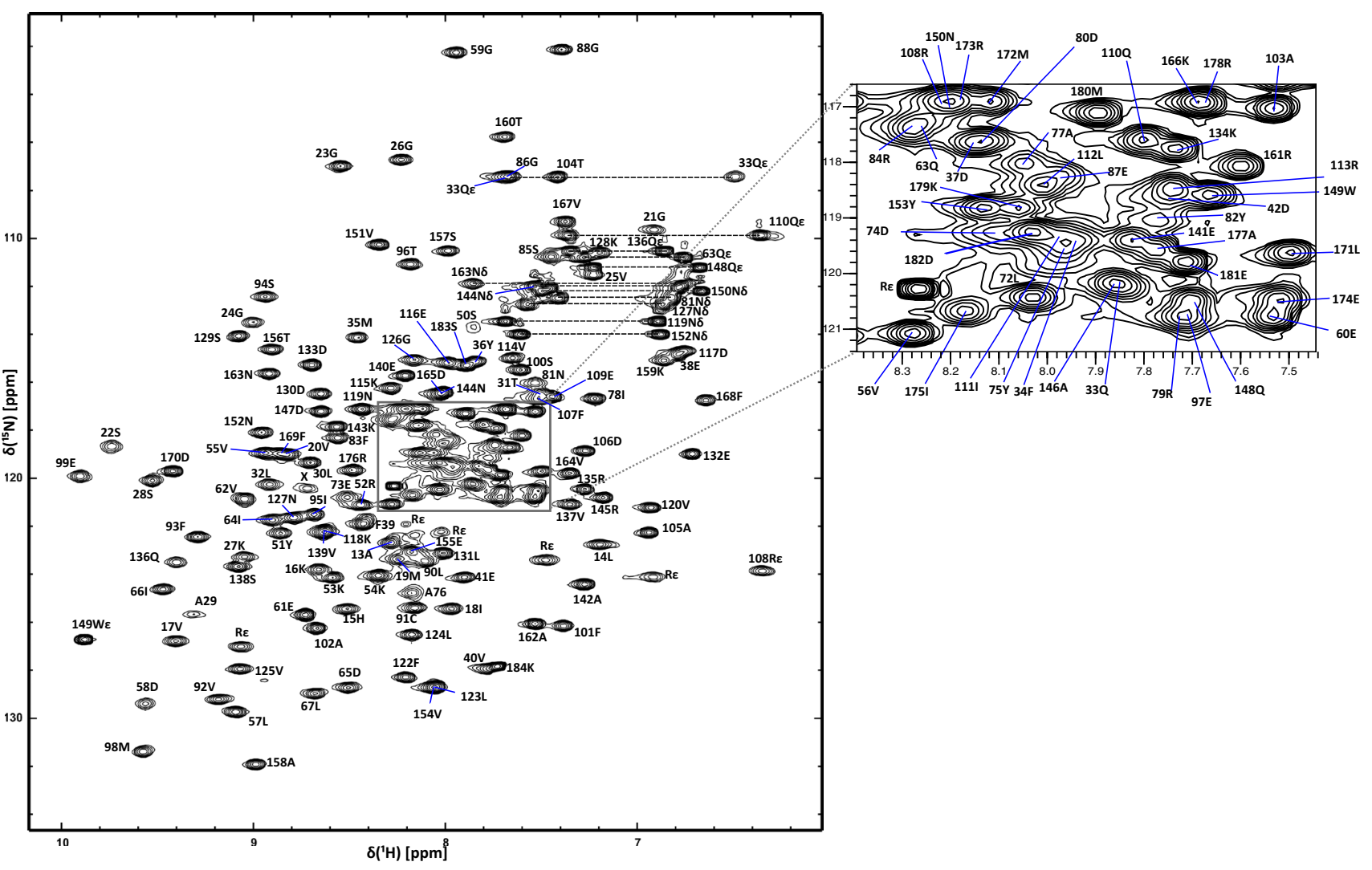

Fig. $1{ }^{1} \mathrm{H}^{15} \mathrm{~N}$ HSQC spectrum of RalA.GMPPNP at $298 \mathrm{~K}$ and $500 \mathrm{MHz}$

RalA.GMPPNP. In addition, sidechains were assigned for residues Thr69 Ala70 in switch II. Outside the two switch regions, aliphatic side-chains for residues 11 to 184 were almost fully assigned except for sidechain carbons of Lys27, Arg176 and Lys179. The ${ }^{1} \mathrm{H}$ and ${ }^{13} \mathrm{C}$ of all proton-bearing aromatic sidechains were fully assigned, except Tyr43 in switch I. He/N $\varepsilon$ were assigned for Arg 108 and $\operatorname{Arg} 135, \mathrm{H} \eta$ was assigned for Tyr 153 and $\mathrm{OH}$ were assigned for Thr31, Ser100, Ser129 and Thr160. All Gln and Asn sidechain $\mathrm{NH}_{2}$ groups were also assigned.
The $\mathrm{H} 1, \mathrm{H} 2$ and $\mathrm{H} 8$ resonances of the purine ring and $\mathrm{H} 1^{\prime}$ of the ribose in GMPPNP were assigned using a $2 \mathrm{D}{ }^{1} \mathrm{H}$ NOESY spectrum. Assignments of RalA.GMPPNP have been deposited in the BMRB database, accession number 28046.

For wt RalA.GDP, backbone amides of all of switch 1 could be assigned and assignments were missing only for Ala70 and Asn81 in switch II. The statistics for the backbone assignments are shown in Table 1 . The ${ }^{1} \mathrm{H}-{ }^{15} \mathrm{~N}$ HSQC spectrum of wt RalA.GDP showing the spectral quality and the assignments is shown in Fig. 2. Assignments of wt RalA.GDP have been deposited in the BMRB database, accession number 28047. 


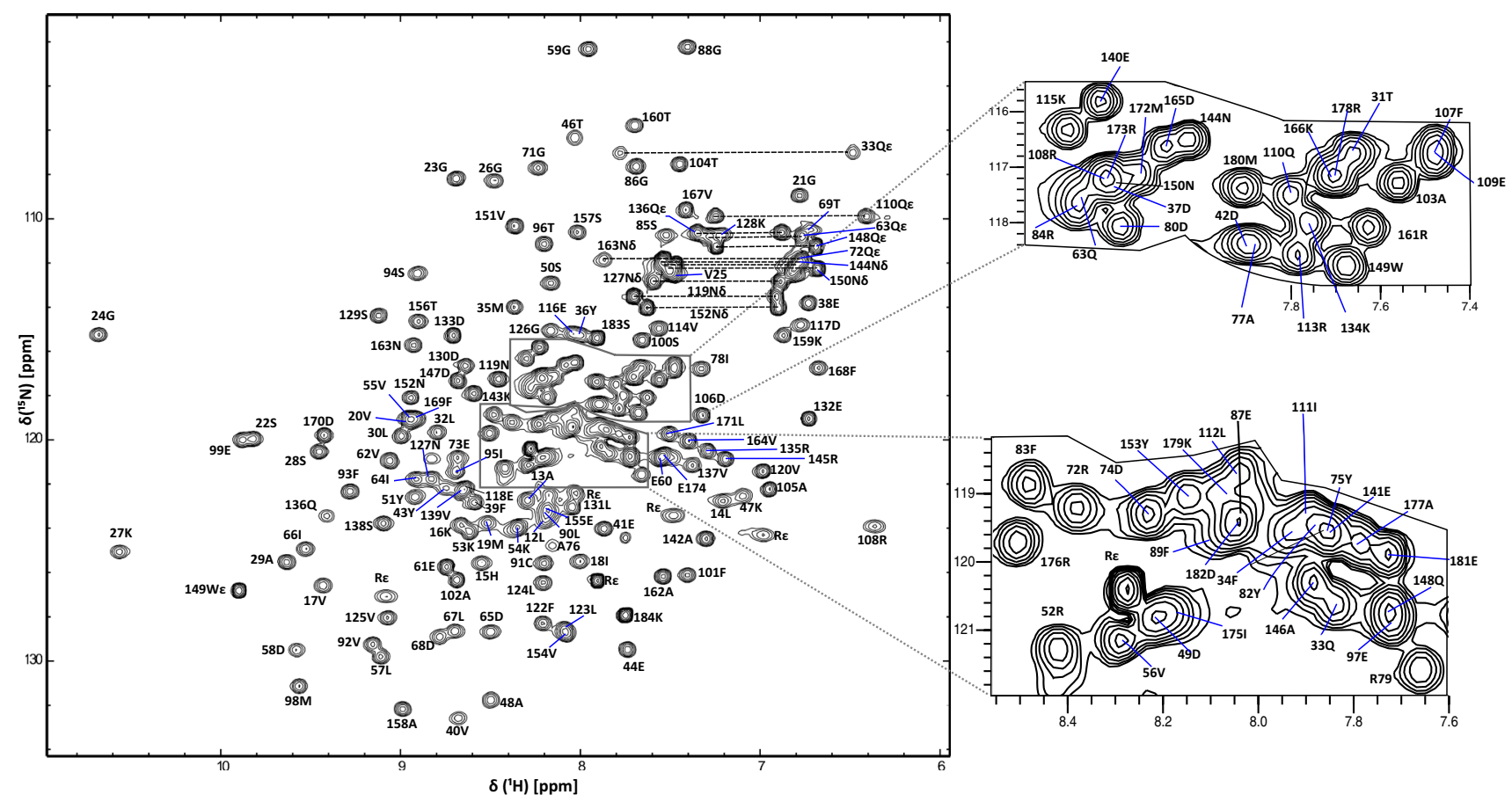

Fig. $2{ }^{1} \mathrm{H}^{15} \mathrm{~N}$ HSQC spectrum of RalA.GDP at $298 \mathrm{~K}$ and $500 \mathrm{MHz}$

Acknowledgements This work was funded by Cambridge Commonwealth, European and International Trust (CCEIT) and Higher Education Commission of Pakistan (HEC) to AS and MRC Project Grants (G0700057 and MR/J007803/1) to DO and HRM. AS is grateful to the Cambridge Philosophical Society for additional support.

Open Access This article is licensed under a Creative Commons Attribution 4.0 International License, which permits use, sharing, adaptation, distribution and reproduction in any medium or format, as long as you give appropriate credit to the original author(s) and the source, provide a link to the Creative Commons licence, and indicate if changes were made. The images or other third party material in this article are included in the article's Creative Commons licence, unless indicated otherwise in a credit line to the material. If material is not included in the article's Creative Commons licence and your intended use is not permitted by statutory regulation or exceeds the permitted use, you will need to obtain permission directly from the copyright holder. To view a copy of this licence, visit http://creativecommons.org/licenses/by/4.0/.

\section{References}

Bodemann BO, White MA (2008) Ral GTPases and cancer: linchpin support of the tumorigenic platform. Nat Rev Cancer 8:133-140

Bourne HR, Sanders DA, McCormick F (1991) The GTPase superfamily: conserved structure and molecular mechanism. Nature 349:117-127

Campbell LJ, Peppa M, Crabtree MD, Shafiq A, McGough NF, Mott HR, Owen D (2015) Thermodynamic mapping of effector protein interfaces with RalA and RalB. Biochemistry 54:1380-1389
Clore GM, Gronenborn AM (1998a) Determining the structures of large proteins and protein complexes by NMR. Trends Biotechnol $16: 22-34$

Clore GM, Gronenborn AM (1998b) NMR structure determination of proteins and protein complexes larger than $20 \mathrm{kDa}$. Curr Opin Chem Biol 2:564-570

Cooper JM, Bodemann BO, White MA (2013) The RalGEF/Ral pathway: evaluating an intervention opportunity for Ras cancers. Enzymes 34(Pt. B):137-156

Feltham JL, Dotsch V, Raza S, Manor D, Cerione RA, Sutcliffe MJ, Wagner G, Oswald RE (1997) Definition of the switch surface in the solution structure of Cdc42Hs. Biochemistry 36:8755-8766

Fenwick RB, Prasannan S, Campbell LJ, Nietlispach D, Evetts KA, Camonis J, Mott HR, Owen D (2009) Solution structure and dynamics of the small GTPase RalB in its active conformation: significance for effector protein binding. Biochemistry 48:2192-2206

Fenwick RB, Campbell LJ, Rajasekar K, Prasannan S, Nietlispach D, Camonis J, Owen D, Mott HR (2010) The RalB-RLIP76 complex reveals a novel mode of ral-effector interaction. Structure 18:985-995

Frankel P, Aronheim A, Kavanagh E, Balda MS, Matter K, Bunney TD, Marshall CJ (2005) RalA interacts with ZONAB in a cell density-dependent manner and regulates its transcriptional activity. EMBO J 24:54-62

Fukai S, Matern HT, Jagath JR, Scheller RH, Brunger AT (2003) Structural basis of the interaction between RalA and Sec5, a subunit of the sec6/8 complex. EMBO J 22:3267-3278

Gardner KH, Kay LE (1998) The use of 2H, 13C, 15N multidimensional NMR to study the structure and dynamics of proteins. Annu Rev Biophys Biomol Struct 27:357-406

Jiang H, Luo JQ, Urano T, Frankel P, Lu Z, Foster DA, Feig LA (1995) Involvement of Ral GTPase in v-Src-induced phospholipase D activation. Nature 378:409-412 
Jin R, Junutula JR, Matern HT, Ervin KE, Scheller RH, Brunger AT (2005) Exo84 and Sec5 are competitive regulatory Sec6/8 effectors to the RalA GTPase. EMBO J 24:2064-2074

Kraulis PJ, Domaille PJ, Campbell-Burk SL, Van Aken T, Laue ED (1994) Solution structure and dynamics of ras p21.GDP determined by heteronuclear three- and four-dimensional NMR spectroscopy. Biochemistry 33:3515-3531

Marion D, Driscoll PC, Kay LE, Wingfield PT, Bax A, Gronenborn AM, Clore GM (1989) Overcoming the overlap problem in the assignment of 1H NMR spectra of larger proteins by use of threedimensional heteronuclear $1 \mathrm{H}-15 \mathrm{~N}$ Hartmann-Hahn-multiple quantum coherence and nuclear Overhauser-multiple quantum coherence spectroscopy: application to interleukin 1 beta. Biochemistry 28:6150-6156

Milburn MV, Tong L, deVos AM, Brunger A, Yamaizumi Z, Nishimura S, Kim SH (1990) Molecular switch for signal transduction: structural differences between active and inactive forms of protooncogenic ras proteins. Science 247:939-945

Mott HR, Owen D (2010) RLIP76 (RalBP1): The first piece of the structural puzzle. Small GTPases 1:157-160

Mott HR, Owen D, Nietlispach D, Lowe PN, Manser E, Lim L, Laue ED (1999) Structure of the small G protein Cdc42 bound to the GTPase-binding domain of ACK. Nature 399:384-388
Prasannan S, Fenwick RB, Campbell LJ, Evetts KA, Nietlispach D, Owen D, Mott HR (2007) $1 \mathrm{H}, 13 \mathrm{C}$ and $15 \mathrm{~N}$ resonance assignments for the small $\mathrm{G}$ protein RalB in its active conformation. Biomol NMR Assignments 1:147-149

Shipitsin M, Feig LA (2004) RalA but not RalB enhances polarized delivery of membrane proteins to the basolateral surface of epithelial cells. Mol Cell Biol 24:5746-5756

Sidhu RS, Clough RR, Bhullar RP (2005) Regulation of phospholipase C-delta1 through direct interactions with the small GTPase Ral and calmodulin. J Biol Chem 280:21933-21941

van Dam EM, Robinson PJ (2006) Ral: mediator of membrane trafficking. Int J Biochem Cell Biol 38:1841-1847

Vranken WF, Boucher W, Stevens TJ, Fogh RH, Pajon A, Llinas M, Ulrich EL, Markley JL, Ionides J, Laue ED (2005) The CCPN data model for NMR spectroscopy: development of a software pipeline. Proteins 59:687-696

Publisher's Note Springer Nature remains neutral with regard to jurisdictional claims in published maps and institutional affiliations. 